Dziawgo L. (2014). Greening financial market. Copernican Journal of Finance \& Accounting, 3(2), 9-23. http://dx.doi.org/10.12775/CJFA.2014.014

\author{
Leszek Dziawgo* \\ Nicolaus Copernicus University
}

\title{
GREENING FINANCIAL MARKET
}

Keywords: ecology, corporate social responsibility, financial market.

J E L Classification: G11, G21, G23, Q56.

Abstract: The idea of Corporate Social Responsibility is one of the most inspiring ideas in modern business, also even in financial business. CSR, already widely implemented in economy, contains significant ecological components. Nowadays, around the world many leading banks, investment funds, pension funds, insurance companies and public companies, use environmental aspects in their business. The growing and diversified ecological engagement of different financial institutions could be even called ecological evolution of financial business.

The same process has started also in Poland. The financial institutions support natural environment in many ways: saving resources, financing proecological organizations, maintaining adequate PR and IR communication and even offering special financial products such as: deposits, payment cards, shares, bonds, investment funds and specialized stock index Respect. Especially, the new investment possibilities are clear evidence of positive changes of the Polish financial market.

The aim of the elaboration is to indicate the phenomenon of environmental rules implementation in Polish financial business. The considerations in the article are focused on financial offer related to natural environment protection. The issue is presented in two aspects: theoretical and empirical.

In the article, critical analysis of literature and reports, analysis of financial market data, induction method and comparison method have been used. Especially, selec-

Date of submission: August 18, 2014; date of acceptance: October 1, 2014.

* Contact information: ldziawgo@econ.umk.pl, Faculty of Economic Sciences and Management, Nicolaus Copernicus University, Gagarina 13a, 87-100 Toruń, Poland, phone: 566112283. 
ted financial products offered on Polish financial market were analysed in the period of 2008-2014 in respect to ecological criteria.

The problem of financial market "ecologization" is a very important subject of scientific research. The process is not only very inspiring, but also controversial.

\title{
ZIELENIEJĄCY RYNEK FINANSOWY
}

Słowa kluczowe: ekologia, społeczna odpowiedzialność biznesu, rynek finansowy.

Klasyfikacja J E L: G11, G21, G23, Q56.

\begin{abstract}
Abstrakt: Idea Społecznej Odpowiedzialności Biznesu jest jedną z najbardziej inspirujących idei współczesnej gospodarki. Staje się coraz popularniejsza również na rynku finansowym. Jak wiadomo, idea CSR dotyczy także ochrony środowiska w prowadzonej działalności gospodarczej. Celem opracowania jest zwrócenie uwagi na ekologiczną ewolucję postępującą na rynku finansowym, ze szczególnym uwzględnieniem polskiego rynku finansowego.

Wprawdzie instytucje finansowe wspierają ochronę środowiska na wiele sposobów, to jednak wiodącym tematem rozważań teoretycznych oraz analizy przypadków praktycznych jest oferta produktów i usług finansowych (wybrane produkty i usługi oferowane w latach 2008-2014).
\end{abstract}

Zwrócono uwagę także na istotne aspekty kontrowersyjne idei CSR.

\section{INTRODUCTION}

The idea of Corporate Social Responsibility is one of the most inspiring ideas in modern business, also even in financial business. CSR, already widely implemented in economy, contains significant ecological components. Nowadays, around the world many leading banks, investment funds, pension funds, insurance companies and public companies, use environmental aspects in their business. The growing and diversified ecological engagement of different financial institutions could be even called ecological evolution of financial business.

The same process has started also in Poland. The new trend in financial business is visible. The financial institutions support natural environment in many ways: saving resources, financing proecological organizations, maintaining adequate PR and IR communication and even offering special financial products such as: deposits, payment cards, shares, bonds, investment funds and specialized stock index Respect. Especially, the new investment possibilities are clear evidence of positive changes also of the Polish financial market.

The aim of the elaboration is to indicate the phenomenon of environmental rules implementation in financial business, especially on Polish financial mar- 
ket. The issue is presented in two aspects: theoretical and empirical. In both areas it is possible to indicate strengths and weaknesses of the ecological evolution idea.

Theoretically, ecological evolution of financial business is not only inspiring, but also controversial. The scale and quality of this process is one of the crucial points for modern economy \& society. The strong hope for better economy and finance is also connected with serious doubts concerning the trustworthiness of ecological policy of financial institutions. One of the problems is: how much the implementation of ecological rules is a matter of necessity, and how much this process is a matter of naivety.

Empirically, there is a lot of significant evidence of convincing engagement of financial business in natural environment protection. The wide range of its proecological activities is really impressive. However, in this article considerations are focused exclusively on financial products related to natural environment protection, since this kind of activity requires, probably, the highest proecological engagement of financial institutions.

To sum up, undoubtedly, the ecological challenge in financial sector is a very important subject of scientific research.

\section{THE RESEARCH METHODOLOGY AND THE COURSE OF THE RESEARCH PROCESS}

In the article, critical analysis of literature and reports, analysis of financial market data, induction method and comparison method have been used. Especially, selected financial products offered on Polish financial market were analysed in the period of 2008-2014 in respect to ecological criteria. The research process was supported by Santander Universidades within program EcoFin.

\section{PROECOLOGICAL ACTIVITIES ON THE INTERNATIONAL FINANCIAL MARKET}

For years, financial market has been involved in supporting proecological transformation of the society and economy and, at the same time, it has been evolving slightly towards "greening" financial market. It is possible to indicate several types of proecological activities in financial business. Up to now, many leading commercial financial institutions have started (scheme 1) (Dziawgo 2003):

- saving natural resources,

- undertaking supporting activities (sponsoring, marketing, education activities), 
- undertaking relationship activities (public relations, investor relations),

- implementing ecological aspects in financial transactions (Dziawgo, Dziawgo 2014).

From the theoretical perspective, all the indicated proecological activities can be also classified as internal environmental care (reducing direct environmental impact - e.g. saving resources) and external environmental care (reducing indirect environmental impact - e.g. ecological risk assessment in financial transactions) (Jeucken 2004, 239).

Scheme 1. Types of proecological activities of financial market institutions

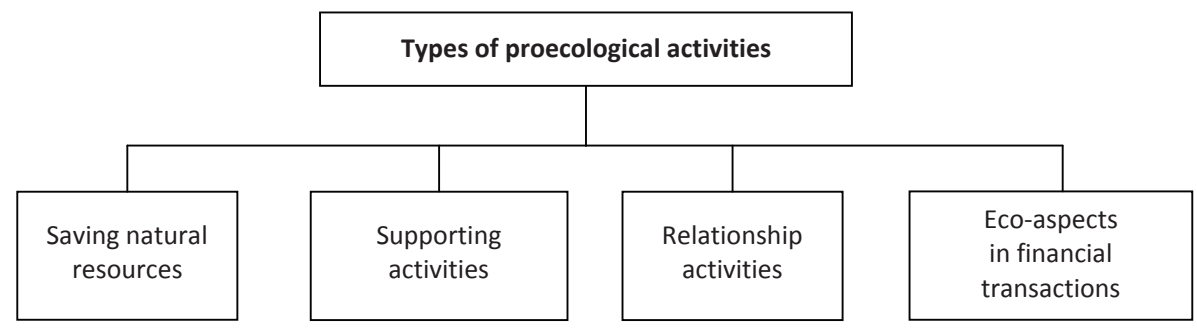

S o u r c e : own elaboration.

Probably, after so many years of proecological policy in financial business, the best known activity of financial institutions for natural environment is saving natural resources by organizing proecological office work. Financial institutions have a relatively very low direct environmental impact. However, to be more ecologically friendly, commercial financial institutions in everyday office work begin to save resources such as: electric energy, heating energy, water, and paper. It is important even to reduce the number and length of business trips due to the greenhouse effect. Certainly, this kind of activities save not only natural resources but also costs.

The second mentioned activity - undertaking supporting activities - concerns financial support of NGO's (specializing in natural environment protection), marketing and education activities, also for staff. The financial support of proecological NGO's is very popular and effective in the creation of ecological image of financial institutions.

The third type of activities - undertaking relationship activities - concerns communication and reporting with the use of ecological aspects to external (e.g. journalist) and internal (shareholders) stakeholders. The adequate presentation of ecological data of their own business activities to both groups of 
stakeholders is very important due to public assessment of the ecological quality of financial institutions.

The last mentioned activity concerns using ecological aspects in financial transactions. As an example we can quote:

- assessing of ecological risk in loan business (this kind of activity leads to the reduction of credit risk),

- offering special financial products and services related to natural environment protection.

Especially, this kind of proecological business activities are not widely known. Investment funds and asset management companies invest capital collected from customers in securities (equities, bonds) of ecologically friendly issuers which are public traded companies. Also banks collect customer savings and invest capital in loans for proecological projects. There is a lot of ecological diversified investment offers in financial business and their number is growing (Werner 2009; Dziawgo 2010).

All proecological activities mentioned above are undertaken due to legal regulations, risk avoidance, profitability, and the pressure of shareholders, customers, investors and the public (Dziawgo 2010). The main aim of all these activities is to be clearly distinguished from other competitive financial institutions. The creation of ecological image by reducing risk and costs in financial business is, at the same time, useful for both natural environment and business condition.

\section{CRITICAL ASSESSMENT OF ECOLOGICAL EVOLUTION}

On the international financial market a lot has been already done for natural environment. These up to date achievements of commercial institutions should be really appreciated. However, it is also possible to indicate some important controversial aspects concerning ecological engagement of financial business. The aim of the critical attitude to ecological activities is not to discredit, but to explain that and, in result, to improve the process of ecological evolution of financial market.

Corporate Social Responsibility and natural environment protection, although more and more popular in everyday business activity, are also to some extent controversial issues, including not only some minor doubts but serious and robust critical voices.

In many cases this criticism is really well-founded and concerns both areas of CSR concept functioning as theoretical (theory) and practical (implementa- 
tion). In both above mentioned areas of CSR concept including ecology, criticism concerns the following aspects:

- real motives of CSR principles implementation,

- scale of CSR activities,

- way of putting CSR principles into practice

and

- effectiveness of CSR activities.

The consideration of the controversial aspects of ecological activities in financial business could be started with the problem of real motives CSR principles implementation in business practice. The issue is of a fundamental importance for CSR idea. Unfortunately, there is absolutely no certainty about the main reason of CSR principles implementation: saving costs, supporting sales or real belief not to harm natural environment. None of the above motives exclude each other, but doubts still exist. The same problem concerns scale and effectiveness of all ecological activities in financial business.

Separately, the case of CSR - concept functioning under the conditions of financial crisis should be considered. The current crisis has resulted in the expected changes of priorities in financial business. In such circumstances the first main target is to continue business activity and save financial institutions from bankruptcy. The ecological aspects are of less importance.

The financial crisis is also a crisis of trustworthiness and one should be reminded that financial institutions are institutions of public trust, or at least they should be. The financial crisis reveals an enormous scale of some financial institutions ruthlessness. The question is obvious: could the same institutions be, at the same time, really ecologically friendly.

The great and diversified ecological engagement of different financial institutions comparing to their huge potential in economic and social life does not look great and diversified enough. This is the next serious problem. Many financial companies undertake some single and superficial ecological initiatives instead of systematic approach, only to create their positive ecological image. Moreover, on the financial market there are even examples of misappropriation of ecological image.

Concluding, creating adequate attitude of financial business to natural environment protection is still a challenge. However, some financial institutions have already started wide, diversified and integrated proecological activities establishing complex system of ecological behaviour of financial business company. 


\section{INTERNATIONAL FINANCIAL MARKET:}

\section{ECOLOGICAL INVESTMENT AND ACTIVITIES - SELECTED EXAMPLES}

According to a reliable estimation, already billlions EUR all over the world are invested in respect to social criteria. A part of it is invested also in respect to ecological criteria (Upgang 2009, 60-69; Gabriel 2007, 82-85; Rotthaus 2009, 43-45). A significant share of this investment business is held by Europe (European SRI Study 2010; 2012). There are many forms of social and ecological investments and activities. Below some selected examples of ecological engagement are presented.

In the international financial market hundreds of so called ethic-ecological investment funds (CSR - and Eco - investment funds) operate and they are becoming very popular ${ }^{1}$. Recently, one of very dynamic markets for this kind of investment activities is German-speaking Europe ${ }^{2}$. The value of this market is already almost 23 billion EUR (2011 - 18 billion EUR) (table 1) (Oeko-Invest 2001, 487; Deml, Blisse 2011).

Table 1. CSR - investment funds in German-Speaking Europe 2014

\begin{tabular}{|l|c|c|}
\hline \hline \multicolumn{1}{|c|}{ Specification } & Number & Amount (EUR mill) \\
\hline \hline Equity funds & 108 & 15,125 \\
\hline Bond funds & 37 & 4,719 \\
\hline Mixed funds & 18 & 2,292 \\
\hline ETF & 7 & 597 \\
\hline Money Market Funds & 2 & 119 \\
\hline Fund of funds & 9 & 129 \\
\hline Total & 181 & 22,981 \\
\hline \hline
\end{tabular}

S o u r c e : Oeko-Invest 2014, 546.

${ }^{1}$ More about investment criteria see: Ulshoefer G. \& Bonnet G. (2009), Corporate Social Responsibility auf dem Finanzmarkt, Wiesbaden: VS Verlag fuer Sozialwissenschaften, 45-63; Dziawgo L. (2010), Zielony rynek finansowy, PWE, Warszawa, 94-106; vigeo.com (accessed: 15.07.2014); Krupa D. (2013), Fundusze SRI we Francji, 125-133 [in:] Rola instytucji i rynku finansowego w świetle celów oraz zasad zrównoważonego rozwoju, G. Borys, A. Janusz (eds.), UE Wrocław.

2 Germany, Austria, Switzerland, Luxembourg. 
A significant part of the above mentioned CSR/Eco-funds belongs to the banks: Deutsche Bank, Credit Suisse, Allianz, Fortis, ING, KBC, Pictet, Raiffeisen, Sarasin, SEB, UBS, ZKB, and HSBC. Some banks are really deeply involved in Socially and Ecologically Responsible Investment. As a good example, a Swiss bank Sarasin can be presented. It specializes in advanced banking business such as Private Banking \& Wealth Management. The bank offers several CSR-investment funds (table 2). The first of them was launched already in 1994.

Table 2. CSR investment funds of Sarasin (2011-2014)

\begin{tabular}{|c|c|c|c|c|}
\hline Name & Type & $\begin{array}{c}2011 \\
\text { - Value: m EUR }\end{array}$ & $\begin{array}{c}2014 \\
\text { - Value: } m \text { EUR }\end{array}$ & $\begin{array}{c}\text { Year } \\
\text { of launching }\end{array}$ \\
\hline Sarasin New Power Fund & equity fund & 97 & 39 & 2007 \\
\hline Sarasin OekoSar Equity Global & equity fund & 257 & 168 & 2005 \\
\hline Sarasin Sustainable Equity Europe & equity fund & 65 & 63 & 2008 \\
\hline Sarasin Sustainable Equity Global & equity fund & 59 & 68 & 1999 \\
\hline $\begin{array}{l}\text { Sarasin Sustainable Equity Global - } \\
\text { Emerging Markets }\end{array}$ & equity fund & 49 & 51 & 2010 \\
\hline $\begin{array}{l}\text { Sarasin Sustainable Equity Real Estate } \\
\text { Global }\end{array}$ & equity fund & 34 & 20 & 2007 \\
\hline Sarasin Sustainable Equity Switzerland & equity fund & 301 & 424 & 1994 \\
\hline Sarasin Sustainable Equity USA & equity fund & 89 & 30 & 2010 \\
\hline Sarasin Sustainable Water & equity fund & 248 & 242 & 2007 \\
\hline Sarasin Sustainable Bond $\mathrm{CH}$ & bond fund & 112 & 74 & 2001 \\
\hline Sarasin Fairlnvest Bond Universal & bond fund & 32 & 19 & 2002 \\
\hline Sarasin Sustainable Bond EUR & bond fund & 151 & 153 & 2003 \\
\hline Sarasin Fairlnvest Universal & mixed fund & 163 & 209 & 2001 \\
\hline Sarasin OekoSar Portfolio & mixed fund & 192 & 239 & 1994 \\
\hline
\end{tabular}

S o u r c e : Oeko-Invest 2011, 487; Oeko-Invest 2014, 546.

The banking sector offers clients the opportunity to invest in a socially \& ecologically responsible way not only through CSR-funds, but also through offering asset management and wealth management or deposits related to financing proecological projects. Another way of ecological investment is investing capital in loans for ecologically friendly companies. Moreover, apart from typical commercial financial institutions, in the financial market operate even 
some specialized banks supporting natural environment in economy - so called ecological banks (UmweltBank - Germany, Bank Ochrony Środowiska - Poland).

For better proecological investing institutional and individual investors use specialized capital market indices such as: Dow Jones Sustainability Index, FTSE4Good, Nasdaq Clean Edge Index, S\&P Global Water Index, S\&P Global Clean Energy Index. Such indices facilitate indicating appropriate investment objectives and measuring their effectiveness.

Also, implementation of procedures related to reducing credit risk by recognition and assessment of ecological risk in loan business can be indicated as a good example of positive evolution towards natural environment protection in modern financial business. Business activities of Swiss bank Credit Suisse can be presented as good practice in this area. Some of Credit Suisse customers operate in environmental sensitive industries such as: forestry, mining, energy, gas \& oil, and chemicals. Transactions with these customers are specially treated by the bank. According to the data, only in 2010 in the scope of Sustainability Risk Assessment 279 transactions in both Americas, Europe, Asia and Africa were assessed (mining 105, forestry 38, oil \& gas 50, energy 24, others 62) (Corporate 2011).

The next type of ecological engagement are activities focused on saving resources - already a substantial part of all ecological activities in financial business. That kind of ecological policy increases the ecological value of shares of financial companies. In many leading banks there were already implemented fully integrated and advanced Sustainable Management Systems. One of such banks is Deutsche Bank. Its system deals with all social and ecological activities of the bank, such as: water use, energy use, paper use, business trips, financial products, cooperation with ecological organizations and many others. The headquarters of the bank in Frankfurt after renovation are regarded as one of the most eco-friendly high-rise buildings in the world (so-called "green towers"). Already eight bank buildings were awarded with LEED (Leadership in Energy and Environmental Design) - 4 in the USA, 3 in Europe and one in India. Even in Wealth Management Business Deutsche Bank has launched specialized financial products (Gesellschaftliche 2010).

Moreover, the leading financial institutions compete for the quality of social and ecological engagement. Banco Santander is a good example of this international competition. The bank in the year 2012 was acknowledged by Bloomberg Markets Magazine as 'World's Greenest Bank', and in 2013 as 'Sustainable 
Global Bank of the Year' by Financial Times and International Financial Corporation (IFC).

In closing, the international activities of financial institutions dealing with ecology should be also raised, such as: UNEP-FI (United Nations Environment Programme - Finance Initiative), PRI (Principles for Responsible Investment), EPFI (Equator Principles Financial Initiative), UN Global Impact, WBCSD (World Business Council for Sustainable Development) or GRI (Global Reporting Initiative).

All the above mentioned specific examples of proecological activities of modern financial markets can be treated as clear evidence of greater proecological engagement of financial business in natural environment protection. However, the crucial point is to use adequately, effectively and reliably the huge financial potential of financial business to support natural environment in economy.

\section{POLISH IMPACT}

The Polish financial market also evaluates towards CSR including ecological criteria. For the first time, Poland was presented in the acknowledged European SRI Study in 2010 edition (European 2011). Obviously, only part of Polish SRI investment can be classified as ecological. Below, some specific examples of proecological financial products of Polish financial institutions are indicated (scheme 2).

The presentation of financial offers should be started from Bank Ochrony Środowiska (Bank of Natural Environment Protection - which is a universal commercial bank - a unique financial institution specializing in financing eco-friendly business Annual 2011). A general assumption of "ecological bank concept" is an entire subordination of all business activities to ecological rules based on economic calculations. According to the above mentioned assumption, the ecological bank collects capital (deposits, bonds, stocks) only for financing business projects of excellent ecological quality. The financed projects are evaluated in the bank with ecological and economic respect. Such a clear treatment of capital seems to be a very competitive advantage. The bank belongs to the group of medium size banks in Poland with the value of balance sheet - more than 4.4 billion EUR (www.bosbank.pl 2014). The additional and important advantage of the bank is the fact that the bank is listed on the Warsaw Stock Exchange (WSE). To promote environmental business projects the bank cooperates with some international financial institutions such as: European Investment Bank 
(EIB), The Council of European Development Bank (CEB) and KfW Kreditanstalt fuer Wiederaufbau. The bank supports natural environment in different areas - not only in business, which is confirmed in 2011 by "Green Office" Certificate awarded by The Environment Partnership Foundation.

Scheme 2. Financial products related to natural environment protection.

Poland 2008-2014

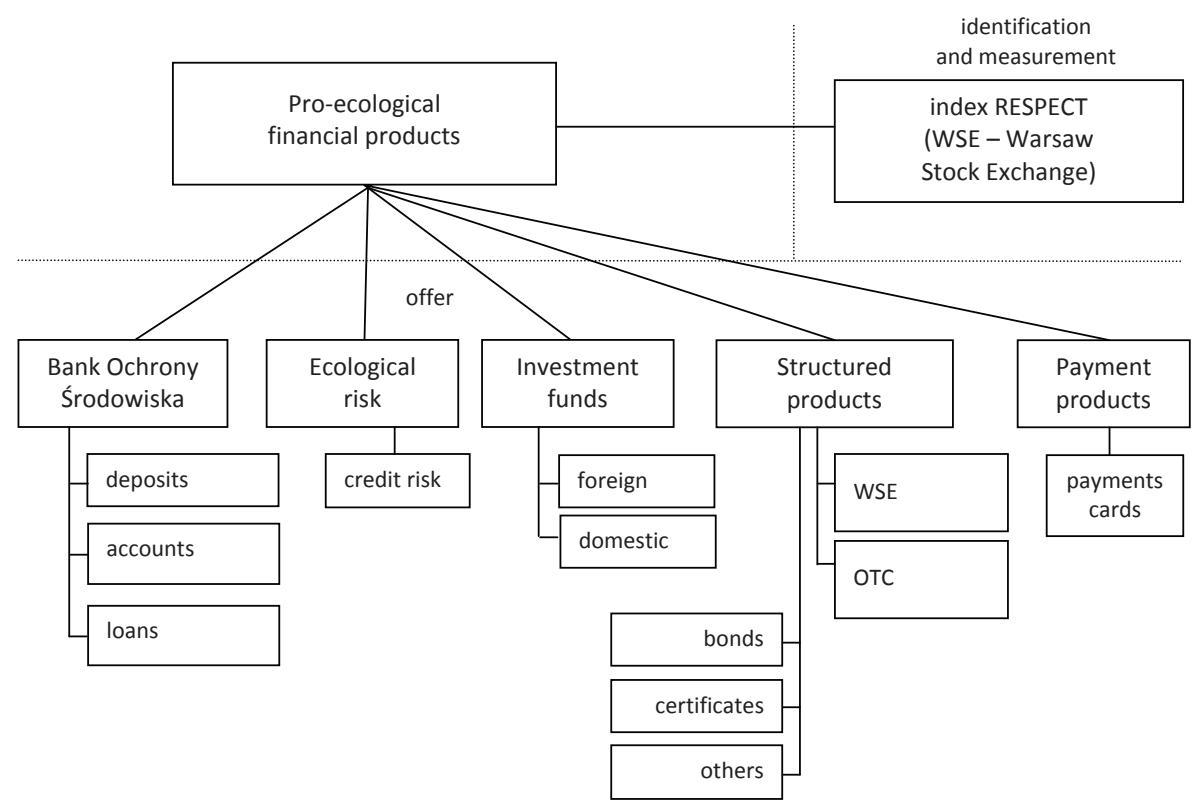

S o u r c e : own elaboration.

Many financial products offered by the BOS bank in the period of 2010-2013 can be indicated as useful for natural environment - below are some examples of loans products:

- Sunny EcoLoan (financing solar collectors),

- Environmentally Friendly Mortgage (financing energy efficient housing),

- Good Energy Loan (financing renewable energy),

- EcoSaving Loan (financing saving energy, heat, water),

- Loan with a Climate (financing projects limiting $\mathrm{CO}^{2}$ emissions) (Ecological 2011; 2013). 
Also deposit products offered by the bank can be acknowledged as very inspiring such as special deposits related to protection of selected endangered species. In this way, clients and the bank together support natural environment. The product has already been used for protection of such species as: wolf, stork, wildcat, gopher, moose, buzzard, and owl.

The second example of positive changes on Polish financial market is Index "Respect" launched on Warsaw Stock Exchange (WSE) in November 2009 as the first CSR Index in Eastern and Central Europe. The name "Respect" is an acronym of words: Responsibility, Ecology, Sustainability, Participation, Environment, Community, and Transparency. At the beginning, new WSE-Index "Respect" consisted of shares of the best 16 public companies from ecological, social and also economic point of view. The index is permanently developing and in 2014 it was expanded to 22 public companies. Moreover, this part of companies represent important part of Polish capital market. The number of public companies including in Respect Index represents approximately $5 \%$ all listed companies, but approximately $27 \%$ stock market capitalization. The representation of CSR companies is even more visible in the most important WSE Index - WIG30. As many as 12 companies from this index are included in Respect Index. It represents approximately $40 \%$ all companies and approximately $46 \%$ capitalization of WIG30.

Another example from the Polish capital market is offering investment certificates, structured products and bonds related to natural environment protection. Financial institutions have already offered the following products: "Good Energy" and "Green Energy" (offered by BRE Bank); "Alternative Energy", "Forestry", "Climate Protection", "Water" (offered by Raiffeisen Bank and listed on WSE); "Friendly Planet” (offered by BZ WBK Santander Group and listed on WSE); "New Energy" (offered by Barclays and listed on WSE). One of the eco-products are also bonds issued by Bank Ochrony Srodowiska.

The next example of proecological engagement is an activity of ethical \& ecological investment funds. In the Polish capital market operate the following funds: DWS Climate Change, Allianz EcoTrends, SKOK Etyczny 1, SKOK Etyczny 2, PZU Energia Medycyna Ekologia, Conerga greenEnergy, BGF New Europe, Arka BZ WBK Energia (Santander Group) and several more (Dziawgo, Dziawgo 2009). A part of them are offered by foreign financial institutions. In turn, the first Polish investment fund specializing in such investments was SKOK Etyczny 1 launched by SKOK in 2008. The same capital group offered the next ethical-ecological investment fund in 2010 - SKOK Etyczny 2 (www.skok.pl). 
The fifth example is CSR and ecological reporting. Many public companies publish information and reports related to ecological issues (Dziawgo 2011, 229-236). The Bank BRE as the first in Poland has implemented GRI standards publishing special CSR annual reports. Some other banks and public companies publish separated and specialized annual reports, such as Millennium Bank (since 2006) or Bank Zachodni WBK Santander Group (since 2013). However, the most popular form of presentation of ecological engagement are company websites used in the scope of investor relations activities (Dziawgo D. 2010, 276-277). The scale of activities of financial business for natural environment protection in saving energy, heat, and water is really growing. There are numerous of examples. One of them concerns so-called Green Branch idea. Deutsche Bank opened in 2010 the first in Poland Green Branch acknowledged by LEED Gold Certificate and already in 2013 Bank Zachodni WBK (Santander Group) confirmed Green Branch certificate for its 33 its branches in Warsaw and Wroclaw (Raport 2013).

Also in payment area ecological changes are visible. A good example is offering payment cards in association with acknowledged ecological organizations such as WWF - World Wide Fund for Nature. The special product of Millennium Bank is affinity payment card of MasterCard. A part of its fee is dedicated to WWF.

The above mentioned facts lead to the conclusion that new trends are visible also on the Polish financial market, where Polish and foreign investors have a wide range of investment offers related to natural environment.

\section{CONCLUSIONS - CHALLENGES AHEAD}

The CSR idea is one of the most inspiring ideas in modern science and business. With the same words also ecological evolution of modern financial market can be described. We all hope for better and fair Economy and Finance. We also hope that social and ecological changes in finance begin a long and hard process of financial business adjustment to requirements of modern society. In this process a greater and more critical engagement of science is needed. Unfortunately, although the process is promising it is also controversial.

The same concerns ecologically responsible investment, as well. After so many years of growing and diversified ecological engagement of financial institutions also this kind of eco-financial activities is finally more significant 
and, at the same time, gives customers new possibilities of investing capital also on the Polish market.

Creating a new proecological model of functioning of financial market we still face a number of challenges. One of them is to use adequately, effectively and reliably the huge financial potential of financial business to support natural environment in economy. The next one is to gain higher awareness and stronger public support for the green evolution of financial business.

This is also a great scientific challenge. The green evolution of financial market requires detailed analyses of offers, investment motives, portfolio selection, effectiveness, risk and other factors. Indicating directions of future research it is necessary to create international and interdisciplinary research teams. The use of selected and diversified methods should be focused not only on financial market, but also on society and natural environment. Such a wider approach seems adequate.

\section{REFERENCES}

Annual Report 2010 (2011), Bank Ochrony Środowiska.

Corporate Responsibility Report 2010 (2011), Credit Suisse.

Deml M. \& Blisse H. (2011), Gruenes Geld, Hampp Verlag, Stuttgart.

Dziawgo D. \& Dziawgo L. (2014), Bankowość wobec kluczowych wyzwań ekonomiczno-cywilizacyjnych. Ochrona środowiska naturalnego w działalności bankowej, 143-158 [in:] Banki w społecznej gospodarce rynkowej. W świetle doświadczeń z kryzysu i stanu rozwoju rynku finansowego, S. Flejterski, A. Gospodarowicz (eds.), Związek Banków Polskich, Warsaw.

Dziawgo D. (2010), Relacje inwestorskie, PWN, Warsaw, 276-277.

Dziawgo D. (2011), Raport roczny w internecie, 229-236 [in:] Raport roczny spółki publicznej, W. Frąckowiak (ed.), Instytut Rachunkowości i Podatków, Warsaw.

Dziawgo L. \& Dziawgo D. (2009). Umweltorientierte Finanzmarktprodukte und Aktivitaeten in Polen, Oeko-Invest, 427.

Dziawgo L. (2003), Eco-offers of Banks and Investment Funds. Poland \& International Trends, UMK, Torun.

Dziawgo L. (2010), Zielony rynek finansowy. Ekologiczna ewolucja rynku finansowego (Greening financial market. Eco-evolution of financial market), PWE, Warsaw.

Ecological Report 2011 (2011), Bank Ochrony Środowiska.

Ecological Report 2013 (2013), Bank Ochrony Środowiska.

European SRI Study 2010 (2011), Eurosif, www.eurosif.org (accessed: 10.06.2014).

European SRI Study 2012 (2013), Eurosif, www.eurosif.org (accessed: 10.06.2014).

Gabriel K. (2007), Nachhaltigkeit am Finanzmarkt, oekom Verlag, Muenchen. 
Gesellschaftliche Verantwortung (2010), Bericht, Deutsche Bank.

Jeucken M. (2004), Sustainability in Finance. Banking on the Planet, Eburon Delft, Delft, 239.

Krupa D. (2013), Fundusze SRI we Francji, 125-133 [in:] Rola instytucji i rynku finansowego w świetle celów oraz zasad zrównoważonego rozwoju, G. Borys, A. Janusz (eds.), UE Wrocław.

Oeko-Invest (2011), 487.

Oeko-Invest (2014), 546.

Raport CSR 2013 (2014), Bank Zachodni WBK Grupa Santander.

Rotthaus S. (2009), Erfolgreich investieren in gruene Geldanlagen, Campus Verlag, Frankfurt/New York.

Ulshoefer G. and Bonnet G. (2009), Corporate Social Responsibility auf dem Finanzmarkt, VS Verlag fuer Sozialwissenschaften, Wiesbaden, 45-63.

Upgang M. (2009), Gewinn mit Sinn, oekom Verlag, Muenchen.

Werner T. (2009), Oekologische Investments, Gabler, Wiesbaden.

www.bosbank.pl (accessed: 14.07.2014).

www.skok.pl (accessed: 12.07.2014).

www.vigeo.com (accessed: 15.07.2014). 
